\title{
Identification of active faults in West Java, Indonesia, based on earthquake hypocenter determination, relocation, and focal mechanism analysis
}

Pepen Supendi ${ }^{1,2^{*}}$, Andri Dian Nugraha ${ }^{3}$, Nanang T. Puspito ${ }^{3}$, Sri Widiyantoro ${ }^{3}$ and Daryono Daryono ${ }^{2}$

\begin{abstract}
We determined earthquake locations through re-picking of P- and S-wave arrival times recorded by BMKG network. Earthquake locations were determined using Hypoellipse code that employs a single event determination method. We then relocated the events using hypocenter double-difference method. We also conducted focal mechanism analysis to estimate the type of fault slip. The results indicate improved hypocenter locations, where patterns of seismicity in West Java were delineated clearly. There are several clusters of earthquakes at depths $\leq 30 \mathrm{~km}$, which are probably related to the Cimandiri, Lembang, and Baribis faults. In addition, there is another cluster in Garut trending southwest-northeast, which is possibly related to a local fault. Histograms of travel-time residuals depict good results, in which travel-time residuals are mostly close to zero. Source mechanism throughout the Lembang fault indicates a left-lateral strike slip in agreement with previous studies. The Cimandiri fault also shows a left-lateral slip, but in the south it shows a thrust fault mechanism. While the source mechanisms of the western part of the Baribis fault indicate a thrust fault and the cluster of events in Garut shows a right-lateral slip if they are related to a local fault.
\end{abstract}

Keywords: Hypocenter determination and relocation, Focal mechanism, Active faults, West Java

\section{Introduction}

West Java has a complex tectonic structure as this region is affected by the Java subduction zone and faults. The subducted Indo-Australian plate beneath the Eurasian plate along Java Island has produced some active faults in West Java, i.e., Cimandiri, Lembang, and Baribis faults and some volcanoes, i.e., Mt. Salak and Mt. Gede-Pangrango in Bogor, Mt. Tangkubanparahu in Bandung, Mt. Guntur and Mt. Papandayan in Garut, Mt. Galunggung in Tasikmalaya, and Mt. Ciremai in Kuningan. Therefore, the western part of Java has high seismic activity (Damanik et al. 2012; Sakti et al. 2012). Based on the historical earthquake data, large earthquakes occurred

\footnotetext{
*Correspondence: pepen_geophysics@yahoo.com

${ }^{1}$ Geophysical Engineering Study Program, Faculty of Mining

and Petroleum Engineering, Institut Teknologi Bandung, Bandung 40132, Indonesia

Full list of author information is available at the end of the article
}

in West Java, e.g., in 1780 and 1834. They are crustal, destructive earthquakes with estimated magnitudes of 8.5 and 7.0-7.7, respectively (Albini et al. 2014; Nguyen et al. 2015; Harris and Major 2016). The Lembang fault was identified as a left-lateral strike-slip fault with an overall length of $29 \mathrm{~km}$ (Afnimar and Rasmid 2015; Daryono 2016). The Cimandiri active fault zone consists of six segments with a predominant sense of reverse motion (Marliyani et al. 2016). Based on CSAMT data it is shown that the Lembang and Cimandiri faults are not connected to each other (Sanny 2017).

These faults are of high potential hazards, because they are located close to densely populated areas. Based on the Central Bureau of Statistics of Indonesia (BPS) data in 2013, the population of West Java was 46,183,642. Most of them live close to the faults. High seismicity due to tectonic activity gives a lot of information to study the subsurface structure. Hypocenter determination and accurate focal mechanism analysis are needed 
to advance our study about characteristics (nature) of the active faults in West Java. The aim of this study is to identify relations between distribution of faults in West Java and seismicity through accurate earthquake determination and hypocenter relocation, and focal mechanism analysis. The results of this study can be used as input for updating earthquake hazard maps in West Java.

\section{Data and method}

In this study, we picked carefully, P- and S-wave arrival times of 3-component waveform using Seisgram2K (Lomax and Michelini 2009), see an example in Fig. 1. The data were recorded by the BMKG seismic stations from May 2009 to December 2015 in the western part of Java and its surrounding areas. There were 168 events that have been determined using Hypoellipse code (Lahr 1979). The method was previously applied to determine earthquakes, e.g., beneath the Merapi volcano in central Java (Ramdhan et al. 2017), in Madiun, East Java (Nugraha et al. 2016), and in West Java (Supendi and Nugraha 2016; Supendi et al. 2018a).

We used HypoDD program (Waldhauser 2001) to run the double-difference method (Waldhauser and Ellsworth 2000) for relocating hypocenters determined in this study. The method assumes that if there are two earthquakes with hypocenter distance smaller than the distance of the hypocenter to the recording station, ray paths from these earthquakes are considered to propagate through a similar medium. HypoDD minimizes residuals between observed and calculated travel-time differences in an iterative procedure, and after each iteration, the locations and partial derivatives are updated. This method has been successfully used to relocate earthquakes in Indonesia using the BMKG data, for example in Sumatra (Ramdhan and Nugraha 2013; Supendi et al. 2017; Nugraha et al. 2018), East Java (Cahyaningrum et al. 2015), Sulawesi (Ismullah et al. 2017; Supendi etal. 2018b), Molucca (Utama et al. 2015; Nugraha et al. 2018), and Papua (Sabtaji and Nugraha 2015). The relocated events facilitate tectonic interpretations in detail.

For selected events in our study area, we used the ISOLA package (Sokos and Zahradnik 2008) to perform moment tensor inversions from at least three BMKG seismic stations (see inverted blue triangles in Fig. 2). Stations at a small epicentral distance were selected. The observed waveforms were pre-processed using a highpass filter with a corner frequency of $0.07 \mathrm{~Hz}$ to $0.15 \mathrm{~Hz}$. For hypocenter determination, relocation, and focal mechanism we used the seismic velocity model resulting from a previous study, i.e., Koulakov et al. (2007).

\section{Results and discussion}

We have successfully located 168 shallow earthquakes (depths less than $30 \mathrm{~km}$ ) recorded from 2009 to 2015 with high accuracy in the mainland of West Java (Fig. 2). Figure 2a depicts some earthquakes that are located away from the faults. To figure out earthquake detection capability of the BMKG seismic station network in West Java, we have plotted earthquake cumulative number (Fig. 3a) and the frequency-magnitude relationship (GutenbergRichter law) using the data from initial location with the maximum likelihood method provided in the Zmap package (Wiemer 2001). The results show that Magnitude of Completeness $(\mathrm{Mc})$ is relatively good for regional networks with 3.3, while the $b$ - and $a$-values are 0.85 and 4.79 , respectively (Fig. 3b).

Here, therefore, we relocated events using the doubledifference method to obtain more precise positions of the hypocenters. The arrival-time catalog data of each event were processed using Ph2dt program in HypoDD packages (Waldhauser 2001). The Ph2dt program seeks for the catalog data of $\mathrm{P}$-and $\mathrm{S}$-wave arrival times to paired events with the same travel time. The parameters used in this study consist of $30 \mathrm{~km}$ maximum hypocentral separation (MAXEP), $50 \mathrm{~km}$ maximum number of neighbors per event (MAXNGH), and the minimum number of links required to define a neighbour (MINLNK) is 8 phases.

We have successfully relocated 117 out of 168 events along the mainland of West Java, while 51 events excluded by the HypoDD were not eligible to be carried out in the relocation process. We compare the relocated events with their initial locations in Fig. 2 and show the histograms of residual times for before and after relocation in Fig. 3c, d. The histogram in Fig. 3b depicts good relocation results, in which the residual times are centered close to zero. Vertical cross-sections of relocated hypocenters shown in Fig. 4 depict hypocenter distributions along the Lembang and, Cimandiri faults, and Garut to the south of Bandung. In the time period of 2009-2015, there were three destructive earthquakes in West Java (see Fig. 2b) occurring on 28 August $2011\left(\mathrm{M}_{\mathrm{L}}\right.$ 3.3), 8 September $2012\left(M_{L} 4.6\right)$, and 18 December 2013 $\left(\mathrm{M}_{\mathrm{L}}\right.$ 4.3).

Based on the National Disaster Management Authority of Indonesia (BNPB), the event on 28 August 2011 $\left(M_{L} 3.3\right)$ caused some damages: 5 houses heavily damaged, 25 houses moderately damaged, and 73 houses lightly damaged in the district of West Bandung. The event is probably due to the activity of the Lembang fault. The destructive earthquake on 8 September 2012 (M4.6) and 18 December $2013\left(\mathrm{M}_{\mathrm{L}} 4.3\right)$ were located in Bogor and Sukabumi regions, respectively. The event of 2012 caused some damages to 567 houses and public 


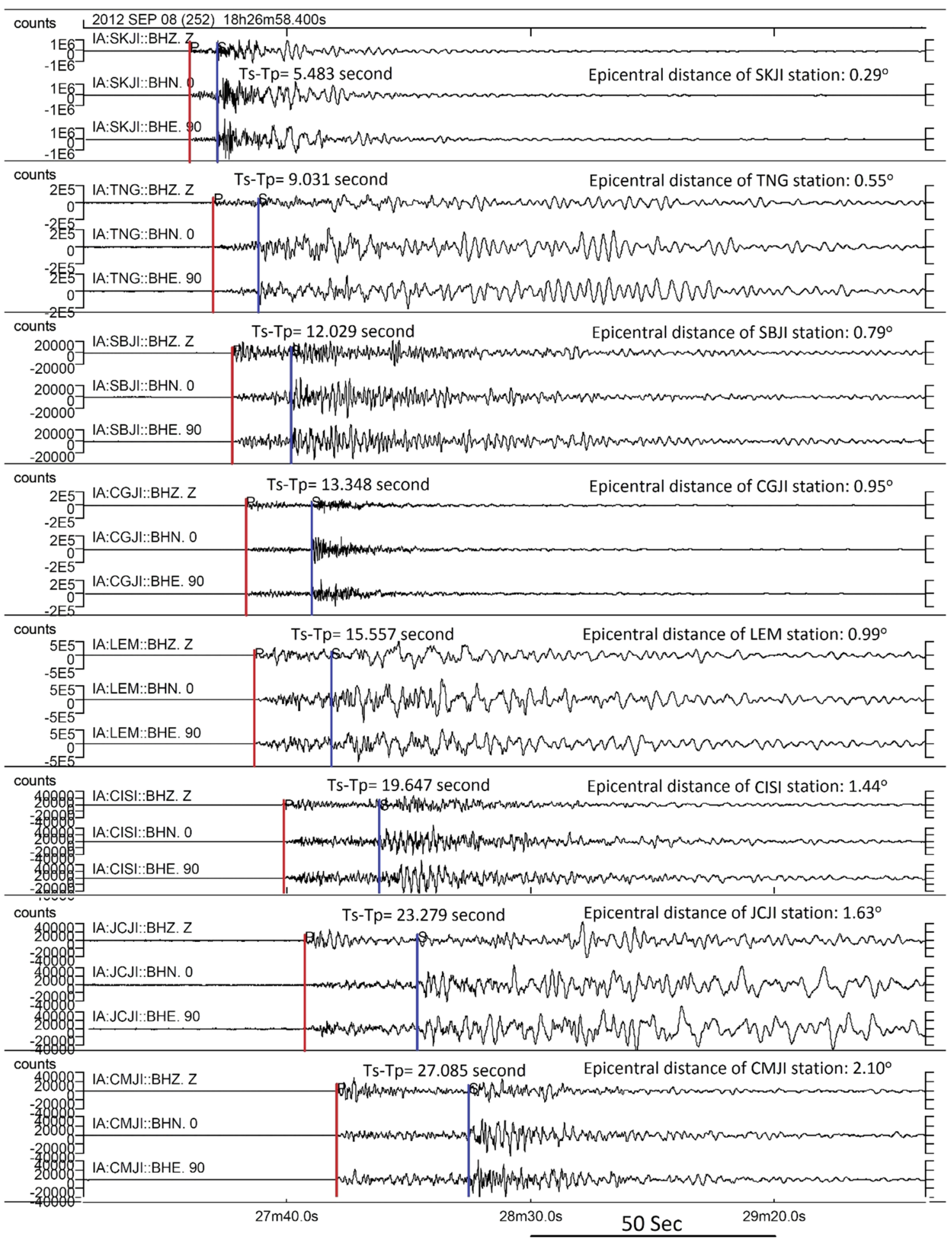

Ts-Tp: The time difference between P- and S-wave arrival times

Fig. 1 Three-component seismogram examples of 8 September 2012 event. From top to bottom, seismograms recorded at stations SKJI, TNG, SBJI, CGJI, LEM, CISI, JCJI, and CMJI (the location of epicenter is shown in Fig. 5). Red and blue lines indicate the picks of P-and S-wave arrival times, respectively 

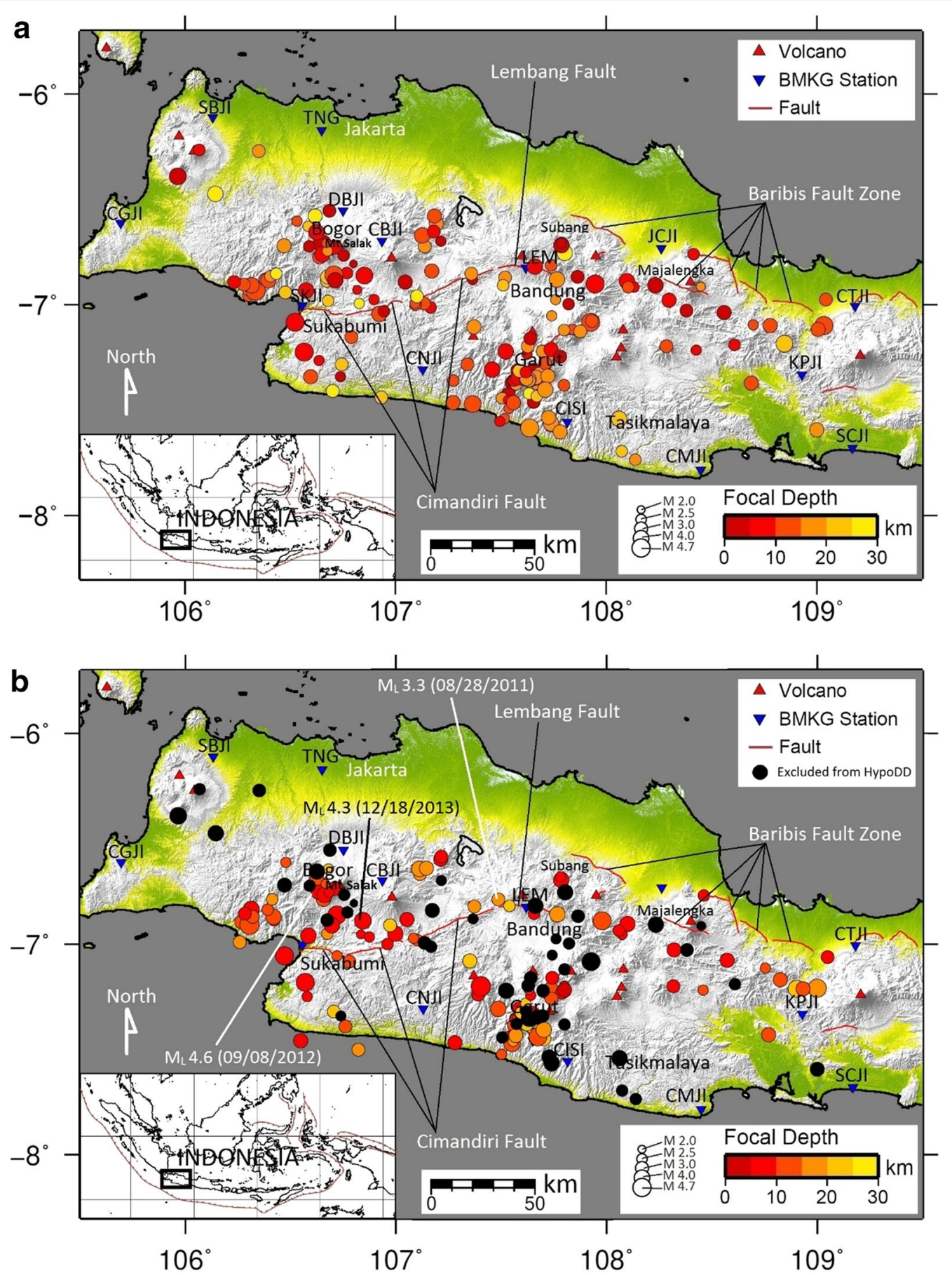

Fig. 2 Map of the shallow earthquakes (depths less than $30 \mathrm{~km}$ ) in West Java in the period from 2009 to 2015. a Initial earthquake locations/ before relocation. b After relocation; there are 168 and 117 events, respectively. Colored dots depict the distribution of epicenters. Black dots depict earthquakes excluded from HypoDD. Blue inverted triangles show the BMKG seismic stations; red triangles depict volcanoes, and the red line depicts a fault from Irsyam et al. (2017)

facilities. 68 public facilities were heavily damaged, 85 moderately damaged, and 414 lightly damaged in the Bogor region. While the event in 2013 caused 2 houses heavily damaged, 18 houses moderately damaged, and 326 lightly damaged in the Sukabumi region. We also plot the destructive earthquakes in West Java before 2009 

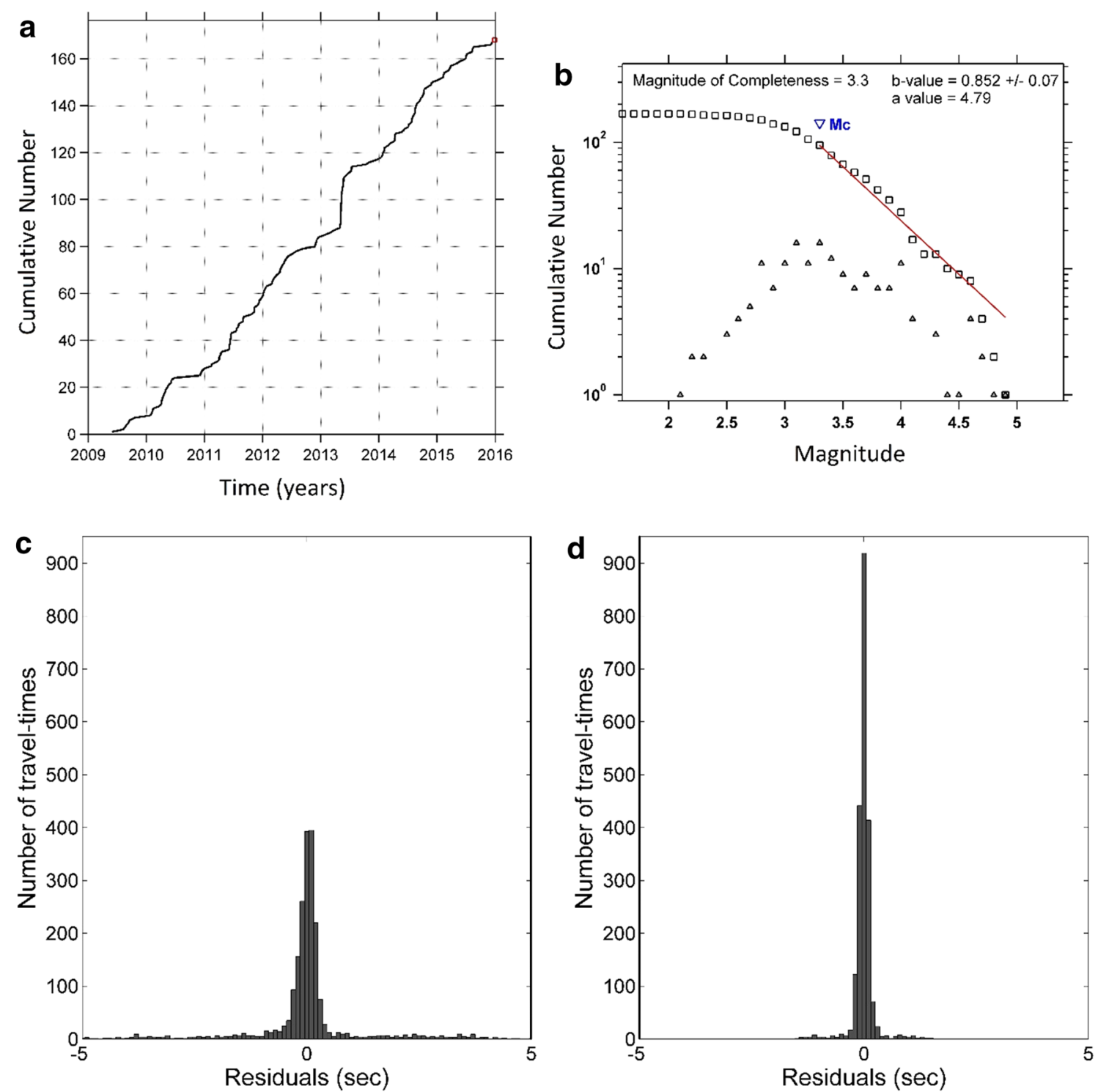

Fig. 3 a Earthquake cumulative number, b earthquake magnitude-frequency relation (Gutenberg-Richter law) for 168 initial locations/before relocation. $\mathbf{c}$ Histogram of travel-time residuals before relocation, and $\mathbf{d}$ after relocation for 117 events

from previous studies (Supartoyo 2008; Musson 2012) as shown in Fig. 5.

We have also derived focal mechanisms through moment tensor inversions for 39 selected events to estimate the type of fault slip (see Fig. 6a) around the Lembang fault (event number 1-4), the Cimandiri fault (event number 5-15), the Baribis fault (event number 24-31), and the Garut cluster (event number 16-23). The new seismic hazard maps of Indonesia (Irsyam et al. 2017) depict that the area of West Java has a high risk due to the seismic activities related to active faults in the region, i.e., the Cimandiri and Lembang faults with a slip rate of $4 \mathrm{~mm} /$ year and $1.5 \mathrm{~mm} /$ year, respectively. However, based on a recent study (Meilano et al. 2012), the slip rate of Lembang fault is $6 \mathrm{~mm}$ /year with a locking at depths of $3-15 \mathrm{~km}$. Our results indicate that there are at least four events along the Lembang fault from 2009 to 2015. One of them caused some damages in the area of the 28 August $2011\left(\mathrm{M}_{\mathrm{L}} 3.3\right)$ earthquake, which was located in western part of the 

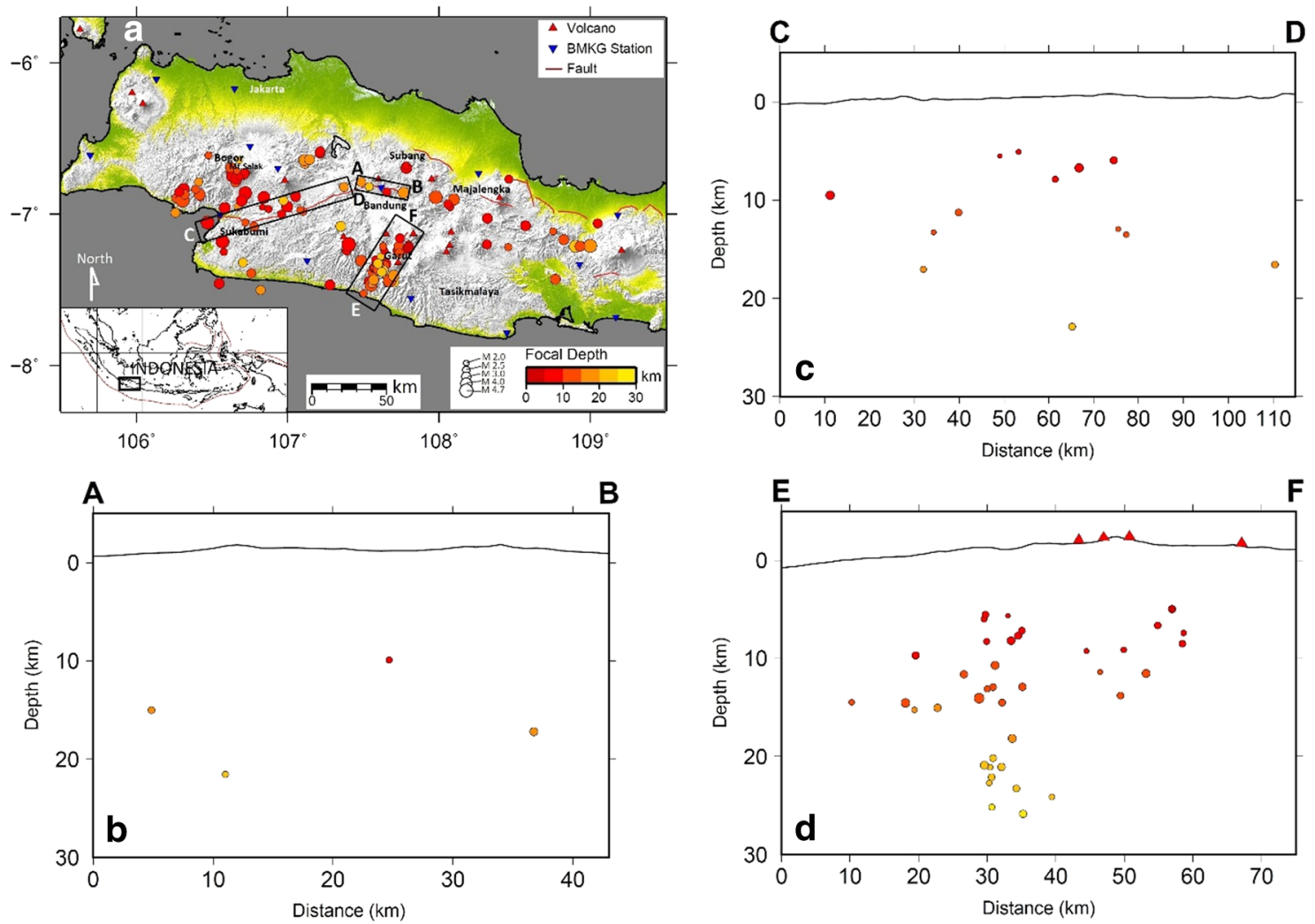

Fig. 4 a Map of relocated earthquakes, and vertical cross-sections along, $\mathbf{b}$ the Lembang fault, $\mathbf{c}$ the Cimandiri fault, and $\mathbf{d}$ the Garut cluster

fault. Our focal mechanism solution is in good agreement with a previous study result (Afnimar and Rasmid 2015), in which the source mechanism along the Lembang fault depicts a left-lateral slip. However, in the eastern part of the fault there was an event with a type of oblique-normal fault.

Along the Cimandiri fault, there were at least ten earthquakes from 2009 to 2015 (event number 5-14 in Fig. 6a). The existence of these events gives a possibility that the fault is active. Based on the previous study by (Dardji et al. 1994), the fault type is left lateral, but (Marliyani et al. 2016) and (Hall et al. 2007) suggest that the Cimandiri fault is a reverse fault. The average horizontal displacement of this fault is $0.5-1.7 \mathrm{~cm} /$ year (Abidin et al. 2009). Our focal mechanism solutions around the Cimandiri fault indicate a left-lateral slip with an oblique dominant thrust fault in the south. The Baribis fault is a thrust fault that extends from Subang to Majalengka in West Java (van Bemmelen 1949). The average horizontal displacement of this fault is $1.0-2.1 \mathrm{~cm} /$ year (Abidin et al. 2009). Along the Baribis fault zone, we have found eight events in the time period from 2009 to 2015, i.e., event number 24-31. The focal mechanism solutions in the western part of this fault zone indicate a thrust fault, while to the east the fault is oblique thrust. We have also found an earthquake cluster in the Bogor area, i.e., in the southern part of Mt. Salak area. The destructive earthquake of 8 September $2012\left(M_{L} 4.6\right)$ was located in this area, in which the focal mechanism solution shows a thrust fault (event number 32 in Fig. 6a). We interpret that this earthquake is due to tectonic activity, i.e., related to an active fault, which is evidenced by fairly clear waveforms recorded by almost all BMKG seismographs in West Java that show tectonic earthquake types.

In the Garut district, interestingly there is a cluster of earthquakes forming a lineament trending in the southwest-northeast direction. Most of the focal mechanism solutions in this cluster indicate a right-lateral fault if lineament originated from a fault activity. We interpret that the events in the Garut district are related to the earthquake event of 2 September 2009 (Mw 7.3) to the south of West Java (Fig. 6). This event was located in 


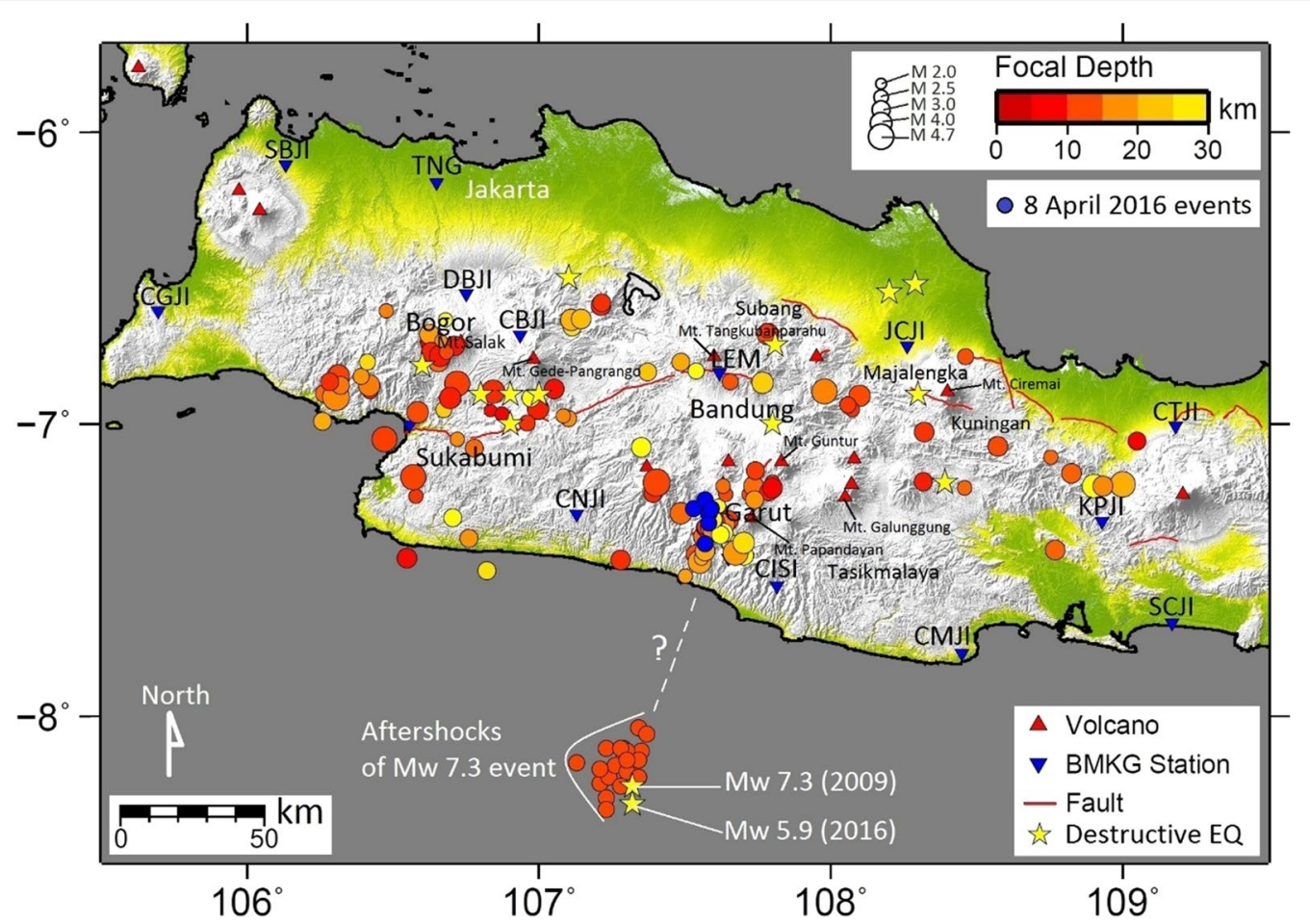

Fig. 5 Relocated earthquakes overlayed with destructive earthquakes in West Java (yellow stars) taken from previous studies (Supartoyo 2008; Musson 2012). The 2009 and 2016 events are probably related to the Garut cluster. Blue dots are the six earthquakes occurring within $48 \mathrm{~h}$ after the 2016 event; the black line is the fault taken from Irsyam et al. (2017). Red triangles depict volcanoes in West Java

the subduction zone between the Indo-Australian and Eurasian plates with a focal depth of $30 \mathrm{~km}$ (based on BMKG data). This event is one of the destructive earthquakes that caused hundreds of fatalities. On 6 April 2016, an Mw 5.9 earthquake occurred close to the 2009 event, but the hypocenter is deeper, i.e., at $65 \mathrm{~km}$ depth (BMKG data). Many people throughout West Java could feel the shaking produced by this earthquake. Two days after this event, i.e., on 8 April 2016, six events occurred within the Garut cluster (the blue dots in Fig. 5) with magnitude less than $M_{L}$ 3.0. With these events, we are convinced that there is a relation between seismicity to the south of West Java and the seismicity in the mainland of West Java, especially in the Garut cluster. As suggested by Shelly et al. (2011), seismic waves could initially trigger a fault creep, which may in turn trigger tremors. Statically triggered seismicity is restricted to regions in the immediate vicinity of an earthquake rupture. Moreover, some observations suggest that dynamically triggered earthquakes and tremors are most likely to occur in regions where seismic waves have previously triggered seismicity (Gonzalez-Huizar et al. 2012). In Garut area there are also several active volcanoes, i.e., Mt. Papandayan and
Mt. Guntur. The seismicity in the South of Java could trigger tremors around the volcanoes, but we interpret that the relocated events in this study are related to tectonic activity, because waveforms were clearly recorded by the BMKG seismic station network located far from Garut. Our observations in Garut are in good agreement with inferences from these previous studies (Irsyam et al. 2017). The earthquakes due to volcanic activities (volcanic earthquakes) are very local, so it can only be recorded by seismographs located close to the volcanoes.

\section{Conclusions}

We have successfully relocated 168 shallow earthquakes in the mainland of West Java in the period from 2009 to 2015 by re-examining seismograms. There are 117 events that have been relocated successfully by applying the double-difference method. The seismicity pattern shows clearly several clusters of events located near active faults in West Java, i.e., Lembang, Cimandiri, and Baribis faults. The focal mechanism around the Lembang fault indicates a left-lateral strike slip in agreement with previous studies. Around the Cimandiri fault the focal mechanism also shows a left-lateral strike slip, but it changes to a thrust 

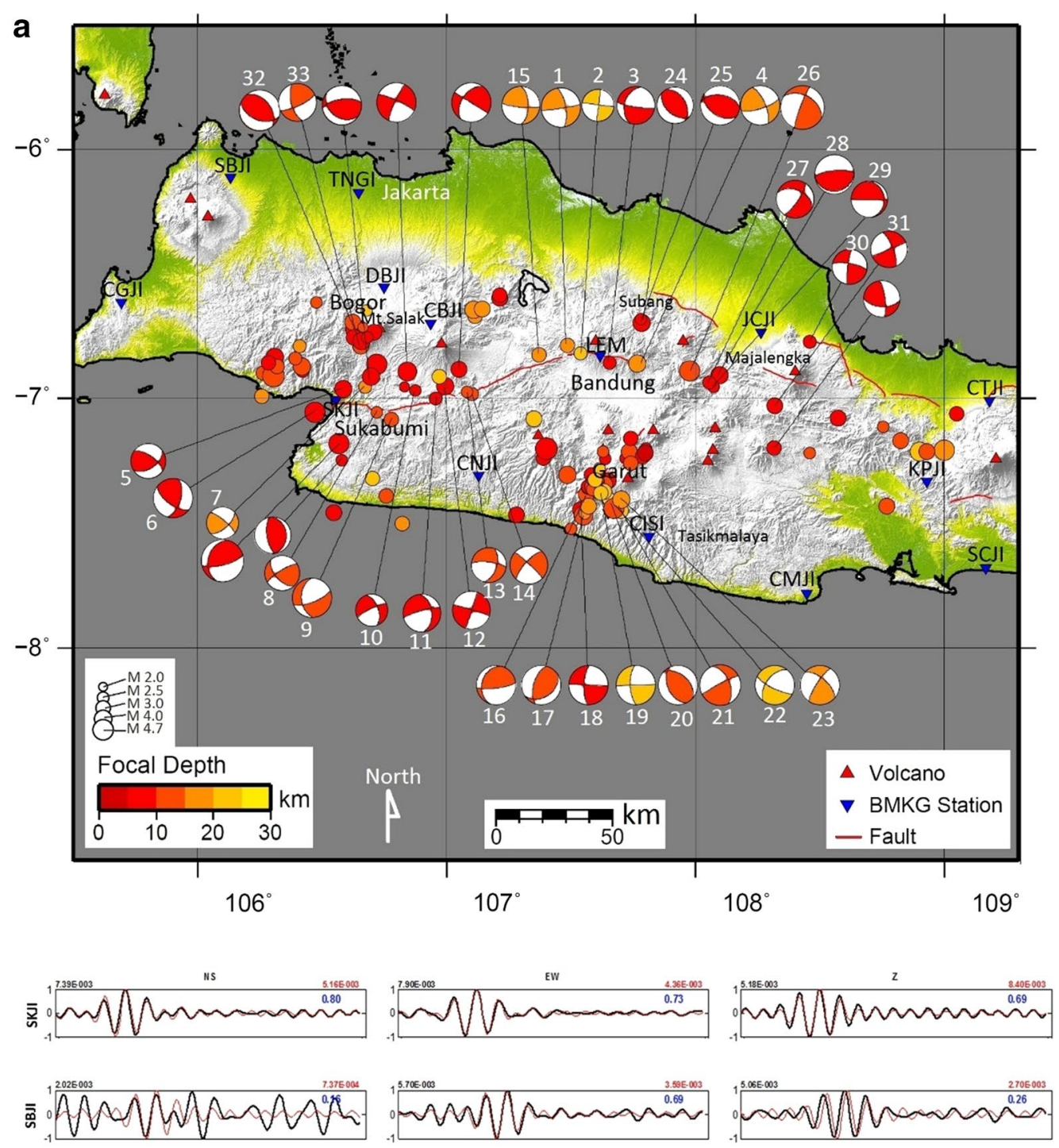

$={ }_{1}^{12965006}$
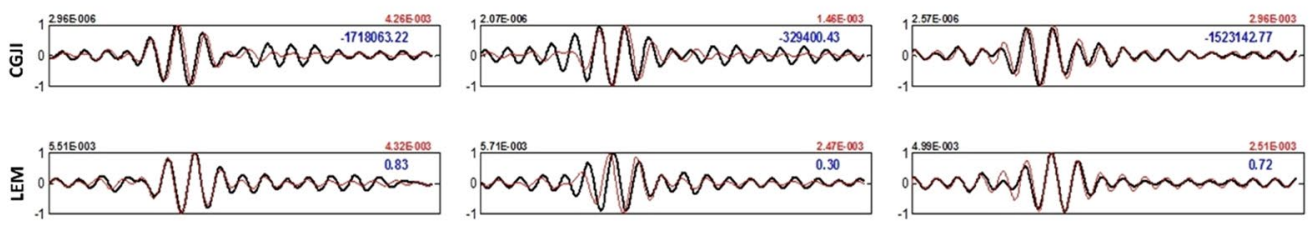

三. ${ }_{1}^{12985003}$
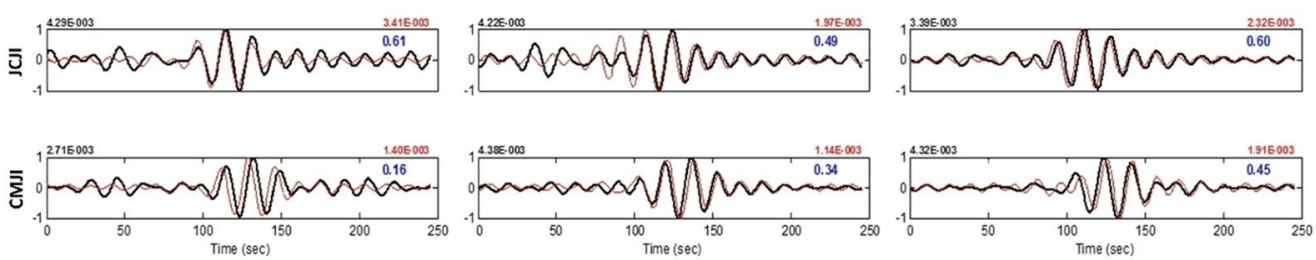

Fig. 6 a Selected focal mechanism solutions of the earthquakes in West Java. b Example of three-component waveform inversions at stations SKJI, SBJI, CGJI, LEM, JCJI, and CMJ of the 8 September 2012 event (number 32 in a). Red and black waveforms are synthetic and observed waveforms, respectively 
fault towards the south. While around the Baribis fault zone, a thrust fault is shown, but it becomes oblique to the east. The cluster of earthquakes in Garut forms a lineament pattern trending southwest-northeast, and most of the focal mechanisms in this cluster show a right-lateral strike slip if the lineament is related to local fault.

\section{Authors' contributions}

PS, ADN, NTP, SW, DD conceived the study; PS, ADN, SW contributed to the writing of the manuscript. All authors contributed to the preparation of the manuscript. All authors read and approved the final manuscript.

\section{Author details}

${ }^{1}$ Geophysical Engineering Study Program, Faculty of Mining and Petroleum Engineering, Institut Teknologi Bandung, Bandung 40132, Indonesia. ${ }^{2}$ Agency for Meteorology, Climatology and Geophysics (BMKG), Bandung 40161, Indonesia. ${ }^{3}$ Global Geophysics Research Group, Faculty of Mining and Petroleum Engineering, Institut Teknologi Bandung, Bandung 40132, Indonesia.

\section{Acknowledgements}

We would like to thank to BMKG for the earthquake data used in this study. We also thank M. Ramdhan, H. A. Shiddiqi and M. Anshori for fruitful discussion. We thank for the constructive and helpful comments from the two reviewers. All figures presented were plotted using Generic Mapping Tools (Wessel and Smith 1998).

\section{Competing interests}

We declare that we have no significant competing financial, professional or personal interests that might have influenced the performance or presentation of the work described in this manuscript.

\section{Availability of data and materials}

'Not applicable' (PS: earthquake data will be shared through our website after this paper is published).

\section{Funding}

This study was supported in part by the Indonesian Directorate General of Higher Education (DIKTI) research funding 2016-2018 awarded to S.W. and research funding 2017 "Penelitian Unggulan Perguruan Tinggi" awarded to A.D.N.

\section{Publisher's Note}

Springer Nature remains neutral with regard to jurisdictional claims in published maps and institutional affiliations.

Received: 3 December 2018 Accepted: 22 December 2018

Published online: 27 December 2018

\section{References}

Abidin HZ, Andreas H, Kato T, Ito T, Meilano I, Kimata F, Natawidjaya DH, Harjono H (2009) Crustal deformation studies in Java (Indonesia) using GPS. J Earthq Tsunami 03:77-88. https://doi.org/10.1142/S1793431109000445

Afnimar YE, Rasmid (2015) Geological and tectonic implications obtained from first seismic activity investigation around Lembang fault. Geosci Lett 2:4. https://doi.org/10.1186/s40562-015-0020-5

Albini P, Musson RMW, Rovida A, Locati M, Gomez Capera AA, Viganò D (2014) The global earthquake history. Earthq Spectra 30:607-624. https://doi. org/10.1193/122013EQS297

Cahyaningrum AP, Nugraha AD, Puspito NT (2015) Earthquake hypocenter relocation using double difference method in East Java and surrounding areas. AIP Conf Proc 10(1063/1):4915029

Damanik R, Triyoso W, Nugraha AD, Zen M (2012) Studi seismic hazard dan analisis risiko dengan pendekatan probabilitas di Pulau Jawa. J JTM XIX:4 (in Indonesian)
Dardji N, Villemin T, Rampnoux JP (1994) Paleostresses and strike-slip movement: the Cimandiri Fault Zone, West Java, Indonesia. J SE Asian Earth Sci 9:3-11. https://doi.org/10.1016/0743-9547(94)90061-2

Daryono MR (2016) Paleoseismology tropis Indonesia (dengan studi kasus di Sesar Sumatra, Sesar Palukoro-Matano, dan Sesar Lembang). Institut Teknologi Bandung (in Indonesian)

Gonzalez-Huizar H, Velasco AA, Peng Z, Castro RR (2012) Remote triggered seismicity caused by the 2011, M9.0 Tohoku-Oki, Japan earthquake. Geophys Res Lett. https://doi.org/10.1029/2012gl051015

Hall R, Clements B, Smyth HR, Cottam MA (2007) A new interpretation of Java's structure. In: Proceedings 31st annual convention Indonesian Petroleum Association. pp 63-86

Harris R, Major J (2016) Waves of destruction in the East Indies: the Wichmann catalogue of earthquakes and tsunami in the Indonesian region from 1538 to 1877. Geological Society, London, Special Publications 441. https ://doi.org/10.1144/sp441.2

Irsyam M, Widiyantoro S, Natawidjaya DH, Meilano I, Rudyanto A, Hidayati S, Triyoso W, Hanifa NR, Djarwadi D, Faizal L, Sunarjito (2017) Peta sumber dan bahaya gempa Indonesia tahun 2017. Pusat Penelitian dan Pengembangan Perumahan dan Permukiman, Kementerian Pekerjaan Umum dan Perumahan Rakyat (in Indonesian)

Ismullah MF, Nugraha AD, Ramdhan M, Wandono (2017) Precise Hypocenter Determination around Palu Koro Fault: a Preliminary Results. In: IOP Conference Series: Earth and Environmental Science. https://doi. org/10.1088/1755-1315/62/1/012056

Koulakov I, Bohm M, Asch G et al (2007) P and S velocity structure of the crust and the upper mantle beneath central Java from local tomography inversion. J Geophys Res. https://doi.org/10.1029/2006jb004712

Lahr JC (1979) HYPOELLIPSE: a computer program for determining local earthquake hypocentral parameters, magnitude, and first motion pattern. USGS Publications Warehouse. https://doi.org/10.3133/ofr79431

Lomax A, Michelini A (2009) Mwpd: a duration-amplitude procedure for rapid determination of earthquake magnitude and tsunamigenic potential from P waveforms. Geophys J Int 176:200-214. https://doi.org/10.1111/ j.1365-246X.2008.03974.x

Marliyani Gl, Arrowsmith JR, Whipple KX (2016) Characterization of slow slip rate faults in humid areas: cimandiri fault zone, Indonesia. J Geophys Res 121:2287-2308. https://doi.org/10.1002/2016JF003846

Meilano I, Abidin HZ, Andreas H, Gumilar I, Sarsito D, Hanifa NR, Salman R, Harjono H, Kato T, Kimata F, Fukida Y (2012) Slip rate estimation of the Lembang fault West Java from GEODETIC OBSERVATION. J Disaster Res 7:12-18. https://doi.org/10.20965/jdr.2012.p0012

Musson RM (2012) A provisional catalogue of historical earthquakes in Indonesia. British Geological Survey, Nottinghamshire

Nguyen N, Griffin J, Cipta A, Cummins P (2015) Indonesia's historical earthquakes modelled examples for improving the national hazard map, Geoscience Australia, https://doi.org/10.11636/record.2015.023

Nugraha AD, Supendi P, Shiddiqi HA, Widiyantoro S (2016) Unexpected earthquake of June 25th, 2015 in Madiun, East Java. AIP Conf Proc. https://doi. org/10.1063/1.4947369

Nugraha AD, Supendi P, Widiyantoro S, Daryono Wiyono S (2018) Hypocenter relocation of earthquake swarm around Jailolo volcano, North Molucca, Indonesia using the BMKG network data: time periods of September 27October 10, 2017. AIP Conf Proc. https://doi.org/10.1063/1.5047378

Ramdhan M, Nugraha AD (2013) Study of seismicity around Toba area based on relocation hypocenter result from BMKG catalogue. AIP Conf Proc. https://doi.org/10.1063/1.4820330

Ramdhan M, Widiyantoro S, Nugraha AD, Métaxian JP, Saepuloh A, Kristyawan S, Sembiring AS, Santoso AB, Laurin A, Fahmi AA (2017) Relocation of hypocenters from DOMERAPI and BMKG networks: a preliminary result from DOMERAPI project. Earthq Sci 30:67-79. https://doi.org/10.1007/ s11589-017-0178-3

Sabtaji A, Nugraha AD (2015) 1-D seismic velocity model and hypocenter relocation using double difference method around West Papua region. AIP Conf Proc 10(1063/1):4915013

Sakti AP, Nugraha AD, Rohadi S (2012) Kajian seismisitas wilayah Selat Sunda dan Jawa bagian Barat menggunakan data hasil relokasi simultan terhadap struktur kecepatan tiga dimensi gelombang P. J JTM XIX:2 (in Indonesian) 
Sanny TA (2017) Identification of Lembang fault, West-Java Indonesia by using controlled source audio-magnetotelluric (CSAMT). AIP Conf Proc. https:// doi.org/10.1063/1.4990889

Shelly DR, Peng Z, Hill DP, Aiken C (2011) Triggered creep as a possible mechanism for delayed dynamic triggering of tremor and earthquakes. Nat Geosci 4:384

Sokos EN, Zahradnik J (2008) ISOLA a Fortran code and a Matlab GUI to perform multiple-point source inversion of seismic data. Comput Geosci 34:967-977. https://doi.org/10.1016/j.cageo.2007.07.005

Supartoyo S (2008) Katalog gempabumi merusak di Indonesia tahun 1629-2007. Departemen Energi dan Sumber Daya Mineral, Badan Geologi, Pusat Vulkanologi dan Mitigasi Bencana Geologi, Bandung (in Indonesian)

Supendi P, Nugraha AD (2016) Preliminary result of earthquake hypocenter determination using hypoellipse around western Java region. AIP Conf Proc 10(1063/1):4947370

Supendi P, Nugraha AD, Wijaya TA (2017) Relocation and focal mechanism of aftershocks Pidie Jaya earthquake (Mw6.5) Dec 7th, 2016 using BMKG Network. Jurnal Geofsika 15:17-20

Supendi P, Nugraha AD, Widiyantoro S (2018a) Recent destructive earthquakes around Garut area, West Java, Indonesia: an unidentified fault? AIP Conf Proc 10(1063/1):5047362
Supendi P, Nugraha AD, Widiyantoro S (2018b) Hypocenter relocation of the aftershocks of the Poso, Sulawesi (Mw 6.6, May 29, 2017) event using the BMKG network data. AIP Conf Proc 10(1063/1):5047361

Utama MRJ, Nugraha AD, Puspito NT (2015) Seismicity studies at Moluccas area based on the result of hypocenter relocation using HypoDD. In: AIP Conference Proceedings. pp 030022

van Bemmelen RW (1949) The geology of Indonesia. Vol. 1 A. The Hague, Govt. Print. Off

Waldhauser F (2001) hypoDD-A program to compute double-difference hypocenter locations. USGS open file report 2001. p. 113

Waldhauser F, Ellsworth WL (2000) A double-difference earthquake location algorithm: method and application to the northern hayward fault, California. Bull Seismol Soc Am 90:1353-1368. https://doi.org/10.1785/01200 00006

Wessel P, Smith WHF (1998) New, improved version of generic mapping tools released. Eos Trans Am Geophys Union 79:579. https://doi. org/10.1029/98EO00426

Wiemer S (2001) A software package to analyze seismicity: ZMAP. Seismol Res Lett 72:373-382. https://doi.org/10.1785/gssrl.72.3.373

\section{Submit your manuscript to a SpringerOpen ${ }^{\circ}$ journal and benefit from:}

- Convenient online submission

- Rigorous peer review

- Open access: articles freely available online

- High visibility within the field

Retaining the copyright to your article

Submit your next manuscript at $>$ springeropen.com 